\title{
COMMENT
}

Received 1 Apr 2016 | Accepted 13 May 2016 | Published 14 Jun 2016

\section{Collaborative encounters? Two recent Spanish takes on the Shakespeare-Cervantes relationship}

Keith Gregor ${ }^{1}$

\begin{abstract}
In the context of the commemoration of the deaths of William Shakespeare and Miguel de Cervantes, this article reconsiders the relationship between these two national icons and its implications for the question of authorship. Since Anthony Burgess published his short story A Meeting in Valladolid in 1989, the possibility of an encounter, whether real or imaginary, between the two men, each learning from the other's fortes and mistakes, has proven an attractive and pervasive one. In Cervantes's own country Spain the idea of an encounter has given rise to (amongst other artifacts) a stage play called Miguel Will, by José Carlos Somoza in 1997, in which Cervantes helps Shakespeare compose a play about Don Quixote and Sancho, and a movie called Miguel y William, directed by Inés París in 2007, in which the romantic rivalry between the two authors is the inspiration for a collaborative theatrical endeavour. After briefly discussing these two texts and the scholarly and popular myths on which they are predicated, I go on to link them to the larger issues of biography, influence and intertextuality. While, with the possible exception of the lost Cardenio, there was no demonstrable collusion between Shakespeare and Cervantes, Miguel Will and Miguel y William seem to suggest alternative modes of "collaboration" that nonetheless fail to challenge or transcend still prevalent notions of writerly authority. This article is published as part of a collection to commemorate the 400th anniversary of William Shakespeare's death.
\end{abstract}

\footnotetext{
${ }^{1}$ University of Murcia, Murcia, Spain
} 


\section{Introduction}

Is it not strange that on this common date, Two titans of their age, aye of all Time,

Together should renounce this mortal state,

And rise like gods, unsullied and sublime? (Service, 1953: 99)

W hen the British-Canadian poet Robert William Service wrote his obituary for Shakespeare and Cervantes, the "strangeness" of their coincidental death dates may not have been felt as deeply as the poet claims. The event, which can be seen as challenging the monotheistic basis of bardolatry, had been fittingly commemorated in the Shakespeare Tercentenary, and the ascension to literary eternity of England's member of what Service terms the "transcendant team" had been the cause of celebration not just in Britain but throughout most of the Empire (Kahn, 2001). Because of its determination to remain neutral in the Great War the Spanish government had been less keen to stress the coincidence (Calvo, 2004), although the pairing of Cervantes and Shakespeare had featured sporadically in critical and pseudocritical tracts from as early as 1832 (Pujante, 2001). Such pairings-usually comparisons, in which Cervantes is presented as a superior, if radically different kind of authorinclude such curiosities as the following "other-worldly" dialogue by José Somoza, in which both authors discuss the differences between them:

CERVANTES. We both were poor, both crippled [sic], both had the world as our master and both attained immortality on the wings of our genius.

SHAKESPEARE. But you were a soldier and I an actor. Your life was restless and mine stationary. Even that strange skill we had in painting fools and in holding up to humanity its hapless image was distinct and opposed in its methods. You made people laugh, I made them cry; I gained immortality through my verse, while you could manage nothing but prose. CERVANTES. But my prose is at least as valuable as your verse. And you would be quite right to mention one other distinction: I wrote to promote reason, you to promote ignorance. (Somoza, 1838: 691)

The first dialogue between Cervantes and Shakespeare as "characters" that I am aware of, the text anticipates the thrust of the 1916 celebrations, by granting both authors a claim to immortality. In a Spanish context, it is also pioneering in that it does at least essay a consideration of the specificities of each writer's medium, its relative merits and purported intention. Typically, however, apart from a certain predilection for madmen and capacity to reflect "reality", it stops short of suggesting any other artistic similarities between them. The Cervantes represented is the author of Don Quixote alone, ${ }^{1}$ a novel which teaches by humorous example, while "Shakespeare" is reduced to the popular, if chiefly tragic, playwright whose main business is entertainment. Both are good at what they do, have similar interests; artistically, however, they are on different wavelengths. ${ }^{2}$ In what follows, I want to pursue the characters of what Service's poem portrays as the "bleak Castilian" and Britain's "starshine of success". My examples are two latetwentieth-century Spanish biographical fictions that stage meetings between the two men: José Carlos Somoza's stage play, Miguel Will (1997), and Inés París's movie, Miguel y William (2007). What representations of the authors do these two texts offer and, in the absence of any biographical evidence to the effect, what grounds do they provide for imagining a collaborative relationship between them? How do they challenge, transcend or, on the contrary, reaffirm still dominant notions of the authorial "myth" to which both have been subject?

As an earlier English-language precedent to some of the ideas raised here, let us recall Burgess's (1989) short story "A Meeting in Valladolid", which imaginatively charts some of the reasons for what the narrator presents as a dis-encounter-reasons, the story suggests, are both national-religious, existential and aesthetic in nature. The putative presence of a Shakespearean First Folio, the property of the first Count of Gondomar and Spanish Ambassador to London, in this northern Spanish city, which at some stage was also home to Cervantes, seems to have been the inspiration for this fictional confluence of talents. In Burgess's story, "Will" Shakespeare has been sent to Valladolid with the rest of his company to accompany a British delegation negotiating the peace with Spain. Their first dramatic offering to the delegates is a truncated version of Titus Andronicus, to sate the Spaniards' appetite for violence. While attending a corrida the next day, Will is struck by the public's acclaim for two figures impersonating Cervantes's Don Quixote and Sancho, characters from a novel he has not read. "The thin mock-knight and his fat squire-they come from a book?", he asks the interpreter, Don Manuel de Pulgar. "Very much so," replies the other. "But they are too big for a book. They have escaped from it as from a prison" (Burgess, 1989: 11). In a subsequent conversation with Cervantes, Will is treated to an angry diatribe against the simulacrum of violence in the Titus production, a consequence, Cervantes argues, of the godless state of the English and their ignorance and incapacity for real suffering: "You do not suffer and you cannot make comedy out of what does not exist in your green and temperate land" (15).

Irked by what Don Manuel interprets as Cervantes's greater "wholeness" (the power of the novel to "render both the flesh and the spirit at one and the same time") and what Cervantes's sees as his characters' ability to "spring from the book and live in unrarefied air" (16), Will determines to offer a hastily rewritten version of his Hamlet. Renamed The Comedy of Hamlet Prince of Denmark, and featuring not just a happy ending but also the characters of Falstaff and Mistress Quickly, the 7-hour production has the unintended effect of accelerating the peace process (nobody wants a repeat performance) and at least gaining the sympathy of the bullfight audience when a "thin tall prince in black and a fat knight in buckram" (20) parade round the ring the following afternoon. But it does nothing to assuage Shakespeare's envy, the sensation that the Spanish novelist had "stolen a march on him in the domain of the creation of universal character" (20). When, a few years later, Don Manuel gives Hemmings and Condell the idea of the simultaneous presentation of Shakespeare's entire production in a single folio edition, he once again hints at the playwright's lack of "wholeness" with respect to Cervantes. His inability to make his characters "spring from the book" is, it is suggested, compounded by the very generic confines of the single play-text and the 2-hour traffic of the production-limits eschewed by Cervantes in his sprawling Don Quixote or, that other popular text cited by Don Manuel: the King James Bible.

Burgess's anti-bardolatrous portrait of Shakespeare is accompanied by a negation of the possibility of a productive interchange with his Spanish counterpart. Not only are the two authors shown as ignoring the other's work-a neglect which, at least until the publication of Shelton's English translation of the first part of the Quixote, was undoubtedly the case-but, with the exception of the "expanded" Hamlet and in the absence of any allusion to the lost Cardenio, any creative capital Shakespeare may have gained from his brush with Cervantes is checked by the pride he takes in his own poetry and by a peevish and somewhat mercantile desire to endow his own characters with some of the "life" of Cervantes. Revising this mutual misprision a few years later, the Cuban-born novelist José Carlos Somoza staged a new encounter in his, to date, 
only play, Miguel Will (premiered in 1997), where the rehearsals for Cardenio are used as pretext for a less-refractory meeting between the pair. Here a tired and ailing Shakespeare is shown in full rehearsal of the play with his King's Men company, struggling to explain the mad knight part to waspish leading actor, Burbage:

BURBAGE. [...] When you gave me the part, you assured me my character was noble, valiant, idealistic ...!

SHAKESPEARE. He is!

BURBAGE. Now you tell me he's a funny lunatic, a fool designed to make the audience laugh ...

SHAKESPEARE. He's that too!

BURBAGE. (Underlining his words as though he were repeating a "law" of the stage) No actor can be both things at once. First choose which I am to be, and then I'll tell you whether I accept! (Somoza, 1999: 27)

Inevitably, the "law" of the Jacobean stage imposes its conditions ("in the theatre no actor can expect the audience to laugh at his ridiculousness at the same time as it listens to him seriously" [36]) and the only way out of the dilemma is, it seems, by means of an extra theatrical ruse: spreading the rumour that Burbage has only accepted the role so as not to disappoint Shakespeare, but that he has vowed to stop acting the moment he hears the audience laugh.

SHAKESPEARE. The audience, knowing that Burbage doesn't want them to laugh, won't be able to stop themselves ... And as Burbage won't know this, he'll carry on acting. And the audience will believe that he's doing it for me, that he's making a supreme effort to carry on acting despite the mockery, and they too will make the effort to take him seriously. That way we will get the audience to laugh cruelly at the character, while taking him seriously at the same time!

\section{Pause. Murmurs of indecision.}

CONDELL. (After the pause) It won't work, Will. The audience will never laugh at one of Burbage's straight characters. They've got too much respect for him.

SHAKESPEARE. They will laugh if they think that he's forbidden them from doing so! Don't you see? The trick is to play on the audience's cruelty ... (50)

Back in Stratford, Shakespeare, whose mind has in any case been wandering, confusing his servants with members of the company or ordinary everyday objects like soup bowls with more grandiose ones like helmets, is then confronted with a series of reflections in the mirror-his own, Burbage's, those of the other actors, whose images remind him of the disjunction between character and actor, and of the crucial part the latter has in giving shape to the former. But the most significant reflection is that of the Spaniard whose story he has been trying to dramatize. It is Cervantes who confronts Shakespeare with the discontinuous nature of the writer's mind, the transformations to which his characters are subject and, above all, the "sacrifices" ("Sleepless nights, fighting windmills, stabbing wineskins, confronting shadows, mad in the head ..." [57]) the author makes to bring them to life. When the "actual", physical Burbage emerges from the mirror and, having got wind of the ruse, announces his decision to play the part anyway ("I don't want to be taken for a coward, and people to think that I'm afraid of facing their mockery" [59]), Shakespeare has already hit upon another plan: to play the part himself, not as "Don Quixote", but in deference to his Spanish counterpart, as "Miguel Will", a man who's lost his wits, not through reading works of chivalry and taking them as real but through "writing plays and [thinking] he's a great playwright" (60).
The premiere of Cardenio is an unmitigated disaster. Shakespeare's "Pirandellian" approach to the performance, situating both himself as "Miguel Will" and "Sancho" among the audience while aping the lines spoken by the character of the mad knight, confounds the naturalistic expectations of both the actors, in their "conventional" roles as Cardenio, Luscinda, Don Alvaro, and so on, and the spectators. Anticipating the disaster, Condell has himself already interrupted the performance by entering through the crowd disguised as a Barber and, with the ending of the true Quixote in mind, has re-scripted the play in such a way that "Luscinda" manages to convince "Miguel Will" to return to his native Stratford and there to slay the "false poetaster" who has been impersonating him, after which he must vow to "remain there and let your pen decline,/Nor write another word" (72). A dignified, if now completely deranged Shakespeare agrees. The final scene shows him once more in Stratford recovering from the debacle, acknowledging his debt to the actors-especially to Burbage who kept the show running - and learning from the obsequious Fletcher that a new version of his Cardenio, retouched to exclude the foolish knight, is now in full rehearsal. Vowing, like the fictional Miguel Will, never to write another word ("I'm tired of writing because writing is like sleepwalking: some things you do well and others you do badly, but you never find out till you're woken by the sound of applause or the cat-calls" [84]), Shakespeare is consoled by a new character, Cervantes-in-a-dream, who claims to have liked the play and who assures him that 'in five hundred years' time, you and I will be considered the greatest writers the world of Literature has known" (85).

Where Burgess's short story could be said to de-authorize Shakespeare in relation to Cervantes, an undoubted flair for poetry hiding the playwright's opportunistic grasp of market forces and complete detachment from "real-life" experiences, Somoza's theatrical "farce" seems to attribute the playwright's aesthetic-as well as physical and psychological-decline to a dissatisfaction with the theatrical conditions of James's England and the literalmindedness of both actors and spectators. As well as being presented in a far less hostile light (he is at times almost fatherly, addressing Will as "son"), Cervantes is here acknowledged as a creative influence, on the one hand laying down the plot for Cardenio and, on the other, resolving (at least in Shakespeare's mind) the contradictions between the "comic" character of the foolish knight and his potentiality for seriousness. But, and here Somoza's background as a trained psychoanalyst becomes conspicuous, this creative influence comes at a price: the pressure on Shakespeare to untie this representational knot leads to what one study terms his progressive "'quixotization', often being incapable of distinguishing reality from fiction" (Pujante and Vera, 2013: 54). His replacement by the conventional Fletcher, whose "cleaned up" and Quixote-less Cardenio is given a command performance by King James, completes the demise, both physical and mental, of Britain's former "starshine of success".

A slightly different take on the Cervantes-Shakespeare relationship is offered by París in her 2007 movie Miguel y William (Miguel and William). The copulative in the title of the film negates any sense of identity between the authors, insisting on their autonomy as independent actors. On the other hand, and very much in keeping with "pop" versions of Shakespeare's life which, in Douglas Lanier's words "are ... concerned less with historical fidelity and more with adjusting (or fabricating) details of Shakespearean biography and reinflecting the mythic structure of Shakespeare the Author (2007: 100)", the film exploits the lacunae of both Shakespeare's and Cervantes's lives to imagine some sort of collaboration between them. ${ }^{3}$ The semi-retired Stratfordian is here replaced by the energetic Shakespeare (played by Will Kemp) of the "lost years", while Cervantes (played by the experienced Juan Luis Galiardo), is still a struggling author, pre-Quixote and indelibly scarred, both physically 
and psychologically, by the injury sustained at Lepanto and years of imprisonment. The encounter is engineered by Leonor de Vibero, the daughter of a Spanish merchant and Shakespeare's former mistress in London, from where she has returned to Spain to marry a widowed Duke. Here she meets Cervantes, whom she beguiles into composing a play to celebrate the wedding and whose imperviousness to female charms she is on the point of undermining, until Shakespeare unexpectedly appears on the scene to prevent her union with the Duke. By far the most resourceful character in the comedy, Leonor passes Shakespeare off as a servant and, since the play is not progressing, manages to persuade both authors to combine their talents to produce a work which, in the words of the film's synopsis, satisfactorily combines Cervantes's "depth and wisdom" with Shakespeare's "mastery of the tricks of the theatre and humour".

In her notes on a production which, it should be noted, was generally maligned for failing to live up to the expectations raised by John Madden's Oscar-winning Shakespeare in Love (Vera, 2011), París reflected on the potential literary pay-backs of such an encounter: "The meeting with Shakespeare could have been the germ for Don Quixote (William would have gone quite mad, lost in the lands he was discovering), Cervantes an inspirer of ... Hamlet? (a man full of doubts, incapable of acting). Othello? King Lear?” (París, 2007). The equivocations are revealing, as well as giving a new twist to what Müller (1991) termed "interfigurality" - that aspect of intertextuality in which literary characters, in this case the authors themselves, are reborn in other writers' works-París attributes to Cervantes a multifacetedness which, as Franssen (2016) has recently illustrated, is reflected in the various literary afterlives of Shakespeare. Such a diversity of roles is, as Andrés Trapiello (2005) has shown, part and parcel of the Cervantes myth (2015: $20)$; slightly less orthodox is its presence in the same text.

Reviewing these and other recent Spanish fictionalizations of Shakespeare's life, Jesús Tronch (2011) has noted a certain tendency to "demystify" both the man and the writer, less as part of a nationalistic desire to reinstate Cervantes as a superior talent than as a desire for alignment with similar bardicidal trends in modern European culture. I agree with this assessment, but would add that such tendencies do not exactly undermine Shakespeare's position at the heart of the Western canon. Rather, they tend to reinforce it-as well as conferring a kind of vicarious "authority" on the texts in which they are displayed. Cervantes's authority is, on the other hand, taken as read, while his contribution to Shakespeare's creativity is, as in Burgess, not reciprocated.

\section{Notes}

1 On the canonization of Don Quixote as the Cervantine text par excéllence in Spain and Latin America, see González Echevarría (1999).

2 The irreconcilable differences between the two "titans" are acknowledged by one of the leading lights of the British tercentenary, Fitzmaurice-Kelly, in the conclusion to his lecture on Cervantes and Shakespeare to the British Academy: "In the exquisite medium of verse, Shakespeare's supremacy is incontestable. But, to be just, we should compare like with like, and if we make the easy experiment of setting a prose passage from-say-As You Like It beside a corresponding passage from Don Quixote, the supremacy becomes doubtful" (Fitzmaurice-Kelly, 1916: 23).

3 Discussions of Shakespearean biography are too numerous to mention. For a consideration of the problems facing biographers of Cervantes, including the identification of the bones recently disinterred at the convent of the Trinitarias in Madrid, see the revised edition of Canavaggio (2015: 21-22; 380-381).

\section{References}

Burgess A (1989) A meeting in Valladolid. The Devil's Mode. Random House: New York, pp 3-21.

Calvo C (2004) Shakespeare and Cervantes in 1916: The politics of language. In Engler B and Bezzola L (eds). Shifting the Scene: Shakespeare in European Culture. Delaware University Press: Newark, DE, pp 78-94.

Canavaggio J (2015) Cervantes. Espasa: Barcelona, Spain.

Fitzmaurice-Kelly J (1916) Cervantes and Shakespeare. First Annual Master-Mind Lecture. Oxford University Press: London.

Franssen P (2016) Shakespeare's Literary Lives. Cambridge University Press: Cambridge, UK.

González Echevarría R (1999) Cervantes and the Modern Latin American Narrative. Ciberletras: Revista de crítica literaria $y$ de cultura 1, https:// dialnet.unirioja.es/ejemplar/57353.

Kahn C (2001) Remembering Shakespeare imperially: The 1916 tercentenary. Shakespeare Quarterly; 52 (4): 456-478.

Lanier D (2007) Shakespeare TM: Myth and biographical fiction. In: Shaughnessy R (ed). The Cambridge Companion to Shakespeare and Popular Culture. Cambridge University Press: Cambridge, UK, pp 93-113.

Müller WG (1991) Interfigurality: A study on the interdependence of literary figures. In: Plett HF (ed). Intertextuality. Walter de Gruyter: New York, pp 101-121.

París I (2007) Como se hizo "Miguel y William", www.labutaca.net/films/48/ miguelywilliam1.htm, accessed 25 March 2016

Pujante AL (2001) Shakespeare or/and...? The Spanish counterpart in the 18th and 19th centuries. In: Sokolova B and Pancheva E (eds). Renaissance Refractions. Essays in Honour of Alexander Shurbanov. St. Kliment Ohridski University Press: Sofia, Bulgaria, pp 157-169.

Pujante AL and Vera N (2013) Shakespeare as character in two works by José Carlos Somoza. Critical Survey; 25 (1): 49-58.

Service RW (1953) Rhymes of a Roughneck. More Collected Verse. Dodd, Mead: New York.

Somoza J (1838) Una conversación del otro mundo, entre el español Cervantes y el inglés Shakespeare. Seminario Pintoresco; 2 (September): 691-692.

Somoza JC (1999) Miguel Will. Iberautor Promociones Culturales: Madrid, Spain.

Trapiello A (2005) Las vidas de Miguel de Cervantes: una biografía distinta. Destino: Barcelona, Spain.

Tronch J (2011) Breaking Shakespeare's image in late Spanish drama and film. In: Thornton Burnett $\mathrm{M}$ and Streete A (eds). Filming and Performing Renaissance History. Palgrave Macmillan: Basingstoke, UK, pp 33-49.

Vera N (2011) Inés París' Miguel y William: Shakespeare's Spanish shipwreck. Unpublished paper presented at the conference of the European Shakespeare Research Association, Weimar, 28 April-1 May.

\section{Acknowledgements}

The article is part of research project FFI2014-53587-P “The reception of Shakespeare's work in Spanish and European culture", funded by the Spanish Ministry of the Economy.

\section{Additional information}

Competing interests: The author declares no competing financial interests.

Reprints and permission information is available at http://www.palgrave-journals.com/ pal/authors/rights_and_permissions.html

How to cite this article: Gregor K (2016). Collaborative encounters? Two recent Spanish takes on the Shakespeare-Cervantes relationship. Palgrave Communications. 2:16033 doi: 10.1057/palcomms.2016.33.

This work is licensed under a Creative Commons Attribution 4.0 International License. The images or other third party material in this article are included in the article's Creative Commons license, unless indicated otherwise in the credit line; if the material is not included under the Creative Commons license, users will need to obtain permission from the license holder to reproduce the material. To view a copy of this license, visit http://creativecommons.org/licenses/by/4.0/ 